\title{
INDEX TO VOL. 32
}

\author{
(including $C R L$ News issues)
}

\section{Prepared by Richard Schimmelpfeng}

\section{ABBREVIATIONS}

Standard abbreviations for names of organizations, ALA, ACRL, LC, etc., are alphabetized as if spelled out. Other abbreviations:

$\begin{array}{ll}\text { appt. } & \text {-appointment } \\ \text { cat.(s) } & \text {-catalog(s) } \\ \text { coll. } & \text {-college } \\ \text { ed. } & \text {-editor, edition } \\ \text { l.(s), ln.(s) } & \text { - library(ies), librarian(s) } \\ \text { port. } & \text {-portrait } \\ \text { ref. } & \text {-reference } \\ \text { rev. } & \text {-review(er) } \\ \text { s(before page numbers) } & \text {-CRL News issues } \\ \text { univ. } & \text {-university }\end{array}$

\section{A}

Abstracts, 59-63; 157-59; 23944 ; $328-31$; $401-05 ; 493-96$

"The academic 1 . looks at union lists," Ellsworth, 475-78

Academic status, s38, 41; s68; s121-25, 127; s153-54; s173$74 ;$ s217; s326-27

Acquisitions, s5-7; s41-43; 45; s68-70; s93, 95; s132, 135; s68-70; s93, 95; s132, 135; s279, 282; s300, 303; s327

Afro-Americana: a Comprehensive Bibliography of Resource Materials in the Ohio State Univ. Ls. by or About Black Americans, Walters, comp., rev. of, 487-88

Alexander, Gerald L., Nicknames and Sobriquets of U.S. Cities and States, $2 \mathrm{~d}$ ed. rev. of, 55

Alternative Press Index, Radical Research Center, Carleton College, rev. of, 51-53

American and British Genealogy and Heraldry: a Selected List of Books, Filby, rev. of, 151

The American Coll. and American Culture. Socialization as a Function of Higher Education, Handlin and Handlin, rev. of, 396-97

ALA, Junior Members Round Table, news, s191

ALA, Social Responsibilities
Round Table Task Force, key address list, s307

Appointments, sI8-21, 23; s5659 ; s82-84; s109-15; s143-44; s193-94; s211-12; s259-60; s288-89; s313-17; s346-49

"An approach to performance budgeting at the Florida Atlantic Univ. L.," Axford, 87104

ACRL, annual conference, Dallas, 1971 , schedule, s128-29, 131

ACRL, Board of Directors, meeting Los Angeles, Jan. 18, 21, 1971 , brief of minutes, s161, 1971, brief of minutes, sl61, las, June 21, 24, 1971, brief of minutes, s225-28, 230-31, 233-39

ACRL, Committee on Academic Status, report, s153-54

ACRL, divisional appointments, 1971/72, s201-04

ACRL, history, s155, 158-60

ACRL membership meeting,

Dallas, June 24, 1971, brief of minutes, s242, 244-45

ACRL, motions enacted by mail ballot, Oct. 1970, s31, 33-34

ACRL, nominating committees for 1972/73, s297-99

ACRL, nominees for offices, $1971 / 72$, s29-30; $s 90$; nominees for offices, $1972 / 73$, nees

ACRL, officers, $1971 / 72$, s221-22
ACRL, president, s160-61

ACRL, Problems in Univ. L. Management, rev. of, 229-30

ACRL, Univ. Ls. Section, 1971 preconference institute, announcement, $\mathrm{s} 90$

ARL, Problems in Univ. L. Management, rev. of, 229-30

Auld, Larry, letter to the editor, $227-28 ; 389-90$

Axford, H. William, "An approach to performance budgeting at the Florida Atlantic Univ. L.", 89-104; "The economics of a domestic approval plan," $368-75$; "A proposal for plan," $368-75$; "A proposal for ence," editorial, 425-26; appt., s55

B

Barnett, Michael P., letter to the editor, 390-92

Barry, James W., rev., 398

Beede, Benjamin $R_{\text {, , letter on }}$ academic status, s326-27

Bell, Jo, letter to the editor, 146 . 47

Beloff. Michael, The Plateglass Univs., rev, of $320-21$

Berlin, Charles, rev., 232-34

The Bibliography of Africa; Proceedings and Papers of the International Conference on African Bibliography, Nairobi, 1967, Pearson and Jones, eds., rev. of, 229 
A Bibliography of Works in English on Early Russian History to 1800 , Crowther, rev. of, 5455

"A bibliography on standards for evaluating ]s.," Ottersen, 12744

The Black Ln. in America, Josey, ed., rev. of, 320

Black Writing in the U.S.A., a Bibliographic Guide, Ryan, rev of 487-88

Blakely, Florence, rev., 149-50

Blosser, Susan B., The Southern Historical Collection: a Guide to Manuscripts, rev. of, 149-50

Boll, John J., Introduction to Cataloging. Vol. 1: Descriptive Cataloging and an Overview of Catalogs and Cataloging, rev. Catalogs and

"Book selection: a national plan for small academic Is.," Massman and Olson, 271-79; comment, 480-82

Books in Singapore; a Survey of Publishing Printing Booksell ing, and L. Activity in the Republic of Singapore, Byrd, rev. of, 317-18

"Books received," 57-59; 154$56 ; 238-39 ; 324-27 ; 399-400$; $489-92$

Boone, Roberta, "Of making many books: a 1. publication program," 3I-35

Boss, Richard W., appt, s 82

Branscomb, Lewis C., ed., The Case for Faculty Status for Academic Lns. rev of 234-36

Brazell, Troy V., Ir., "Comparative analysis: a minimum music materials budget for the univ. 1.," $110-20$

Brichford, Maynard J., Scientific and Technological Documentation: Archival Evaluation and Processing of Univ. Records Relating to Science and Technology, rev. of, 484-85

Bryan, Harrison, The Function of the L. in a Coll. of Advanced Education, rev. of, 487

Buckland, Michael et al., Systems Analysis of a Univ. L.; Final Report on a Research Project, rev. of, 152-53

Burns, Martha A., Student Activism in American Higher $E d-$ ucation, rev. of, 322-23

Burns, Robert W., "A generalized methodology for l. systems methodology for 1. systems
analysis," 295-303; rev., 23638

Byrd, Cecil K., Books in Singapore; a Survey of Publishing, Printing, Bookselling, and $L$. Activity in the Republic of Singapore, rev. of, 317-18

\section{C}

California Local History: a Bibliography and Union List of $L$. Holdings, $2 \mathrm{~d}$ ed., rev. and enl., Rocq, ed., rev. of, $4 \dot{8}-49$

"Can academic lns. afford C\&RL?" Dougherty, editorial, 85-86; comments, 381-84

Carmack, Bob, "The I. reserve system-another look," 105 09 ; comment, 228, 315

Carper, Ann M., letter to the editor, 383

Cartwright, Kelley L,, rev., 152 53

The Case for Faculty Status for Academic Lns., Branscomb ed., rev. of, 234-36

Center for Research Ls., 1970 census data access program s65, 67

Chapman, Edward A., L. Systems
Analysis Guidelines, rev. of, 318-19

"Comparative analysis: a minimum music materials budget for the univ. 1.," Brazell, $110-$ 20

"A comparison of two methods of 1 . instruction for students in introductory biology," Kirk 465-74

Computer-Based L. and Information Systems, Henley, rev. of, $151-52$

Cooper, Michael D., "Cost accounting and analysis for univ. ls.," 449-64

Cooperation Between Types of Ls., 1940-1968: an Annotated Bibliography, Stenstrom, rev. of, 485-86

"A cooperative interl. loan service for the state-assisted univ. Is. in Ohio," Schmidt and Shaffer. 197-204

Cooperative Resources Development: a Report on a Shared Acquisitions and Retention System for METRO Ls., Simkin, rev, of, $483-84$

Corbin, John B., letter to the editor, 316 ; rebuttal, 479,480

"Correlating the subjects of books taken out of and books used within an open-stack 1., McGrath, 280-85; comment, 482

Cosgriff, John, letter to the editor, 38

"Cost accounting and analysis for univ. Is.," Leimkuhler and Cooper, 449-64

Crawford, Miriam, rev., 484-85

Crowther, Peter A., A Bibliography of Works in English on Early Russian History to 1800 rev. of, 54-55

Cunningham, William Dean, appt., s288

\section{$\mathrm{D}$}

Dale, Doris Cruger, The United Nations L.: Its Origin and Development, rev, of, 321-22

Danton, J. Periam, letter to the editor, 64

Davis, Donna G., "Security problems in coll, and univ. ls.: student violence," 15-22

Davis, Jo-Ann, "Of making many books: a l, publication program," 31-35

Davis, Richard A., letter to the editor, 389

De Gennaro, Richard, appt, , s55

DeHart, Florence E., rev., 14849

"Democratization and the ALA Council," Shank, editorial, s219

Demos, John Theodore, appt. \& port., s193

Dougherty, Richard M., "Can academic Ins. afford C\&RL?" editorial, 85-86, comments, 381-84; "Legislative naivete of lns.," editorial, 18I; Management and Costs of Technical Processes: a Bibliographical Review, 1876-1969, rev. of, 148-49

\section{E}

East Central Europe; a Guide to Basic Publications, Horecky, ed., rev. of, 46-48

Eaton, Andrew J., "Fund raising for univ. ls.," 351-6I

Eaton, Nancy L, rev, 23I-32

"The economics of a domestic approval plan," Axford, 368-75

The Economics of Book Storage in Coll. and Univ. Ls., Ellsworth, rev, of, 50-51

Edelman, Hendrik, rev., 229
Edelstein, J. M., rev. 55-57

Edmonds, Anne C., "Railroad tracks and alphabet soup," editorial, 269-70; "From the ACRL President," s160-61

Edwards, Elza Ivan, The Enduring Desert; a Descriptive Bibliography, rev, of, 320

El-Khawas, Elaine, "An overview of the first four years of the Title II-B fellowship program," 205-16

Ellsworth, Dianne, "The academic 1. looks at union lists," 475 78

Ellsworth, Frank L., Student Activism in American Higher Education, rev. of, 322-23

Ellsworth, Ralph E. The Economics of Book Storage in Coll. and Univ. Ls., rev, of, 50-51

Elrod, J. McRee, letter to the editor, 145; comment, 3I5-16

The Enduring Desert; a Descriptive Bibliography, Edwards, rev. of, 320

\section{F}

Die Fachliteratur zum Buch- und Bibliothekswesen, 9. Ausg., rev. of, $319-20$

Farley, John, rev., 486-87

Ferguson, John, Ls. in France, rev. of, 484

Filby P. William, American and British Genealogy and Heraldry: a Selected List of Books, rev. of, 151

Flanagan, Cathleen, rev., 484

Florida Atlantic Univ. L., 87-104

For the Government and People of This State: a History of the New York State L., Roseberry, rev. of, 486-87

Forth, Stuart, rev., 323-24

Foskett, A. C., The Subject Approach to Information, rev. of 153-54

"From inside the DLP." Stokes, s1-2; s37; s67; s91; s13I-32; s175; s205; s246; s278

The Function of the L. in a Coll. of Advanced Education, Bryan and Hean, rev, of 487

"Fund raising for univ. 1s.," Eaton, 351-61

\section{G}

Gaines, Ervin J., rev., 50

"A generalized methodology for . systems analysis," Burns, 295-303

Gibson, Mary Jane, letter to the editor, 228

Goode, Stephen H., comp., Index to American Little Magazines 1920-1939, rev. of, 55-57

"The great gas bubble prick't; or Computers revealed-by a gentleman of quality," Mason 183-96; comment, 316 , 388 92,480

"The greening of the 1.," Webb, 5; comment, 227-28

Guidelines for Two-Year Coll. L. Learning Resource Centers," text, s265-78

\section{$\mathrm{H}$}

Handbook of Medical L. Practice, $3 d$ ed., Medical L. Association, rev, of, 397-98

Handlin, Mary $\mathrm{F}$. The American Coll. and American Culture. Socialization as a Function of Higher Education, rev. of, $396-$ 97

Handlin, Oscar, The American Coll. and American Culture. 

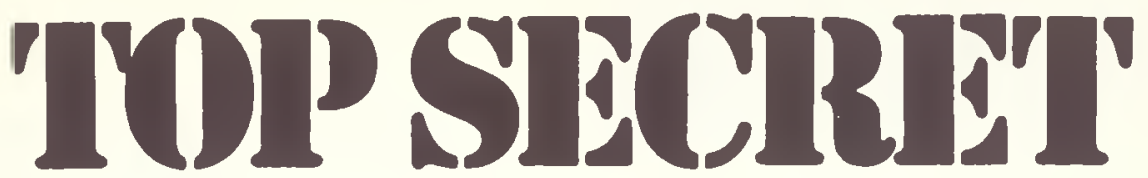

If you haven't already ordered WIPIS ${ }^{\text {TM }}$ for 1971, then you might as well consider the information it contains top secret! Data in the 1971 Annual of ISI's WHO IS PUBLISHING IN SCIENCE ${ }^{\mathrm{TM}}$ just isn't available from any other single source.

Only ISI's unique multidisciplinary data base can give you the names and current addresses and organizational affiliations of more than 230,000 scientists and technologists who had a journal article published during 1970. Scientists from over 35,000 organizations around the world are included - scientists whose research work ranges from experimental to applied.

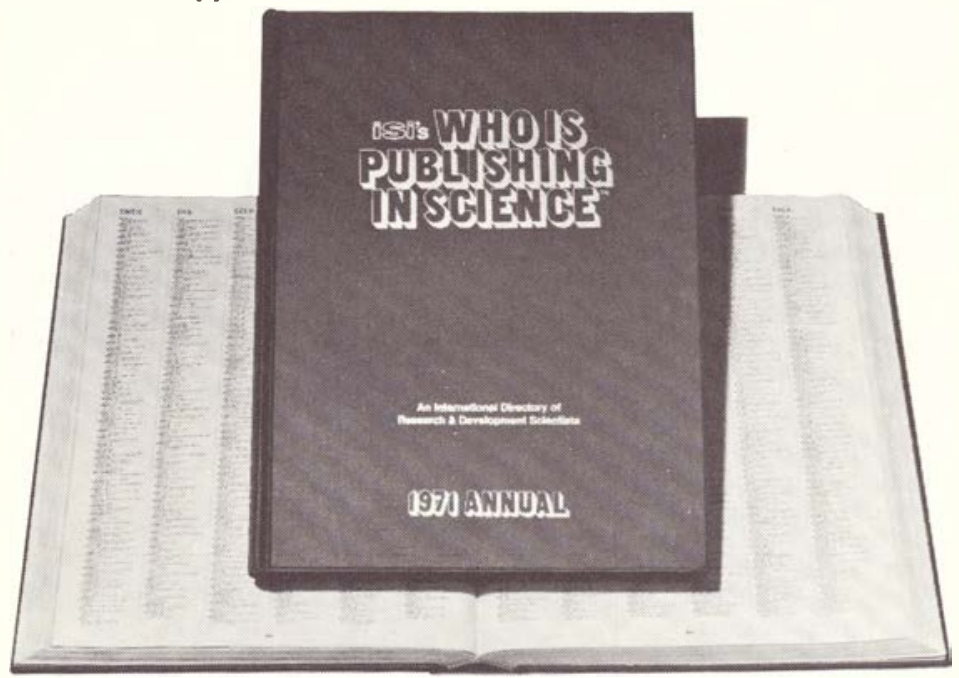

With WIPIS you can

- Help your patrons keep in touch with colleagues, exchange ideas, arrange meetings, or request reprints

- Check the level of scientific writing activity at specific organizations and their various departments

- Identify and locate little-known organizations - especially foreign ones

- Verify authors' names for bibliographies

And WIPIS is easy to use. Indexing by name, organization, and geographic location makes it possible for anyone to use WIPIS without your constant guidance.

Result: Your patrons can help themselves while you work on other projects.

Now that we've disclosed some of the details of WIPIS, we'll be happy to totally de-classify our top secret data for you. Use the coupon to order.

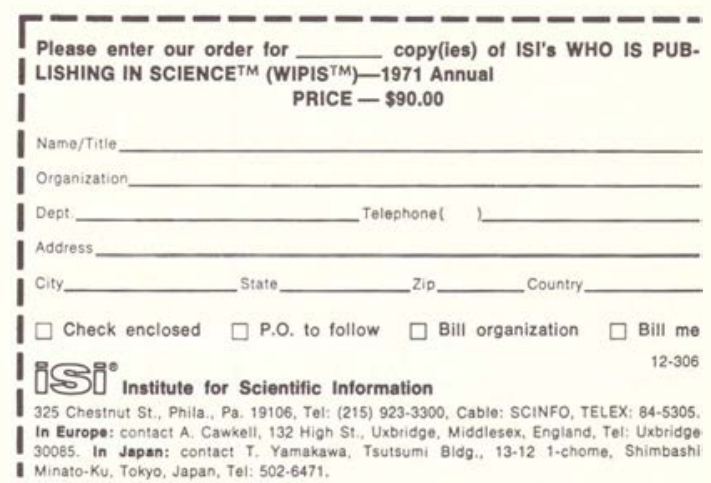


"An impressive... dual media collection [a] monumental work

Joe Morehead, RO, Spring 1971

\section{The United States Histo}

by special arrangement $w$ and the Acting Superintenden



UPDATES THE 1909 CHECKLIST AND OTHER BASIC REFERENCE TOOLS USED BY DOCUMENTS LIBRARIANS

Here's how the two standard reference books on U.S. Government documents evaluate the public Documents Library, its collection, the SuDocs Classification scheme, and the need for updating the predecessors of Checklist "70.

GOVERNMENT PUBLICATIONS AND THEIR USE,

L. F. Schmeckebier and R. B. Eastin, 2nd Revised

Edition, Brookings Institute, 1969.

"There is probably no complete collection of government publications in existence, but the one in the Public Documents Library is probably the most nearly complete... it has all issues listed in the Monthly Catalog and the biennial Documents Catalog. It also has some material not so listed, as back issues are often sent to the library after the catalogs are printed."

UNITED STATES GOVERNMENT PUBLICATIONS, A. M. Boyd and R. E. Rips, 3rd Revised Edition, Wilson, 1953.

"The Library of the Office of Superintendent of Documents is of interest to librarians ... because of the classification scheme by which its collection is arranged. It has been adopted by many other libraries throughout the country as a most convenient and satisfactory method of organizing and arranging collections of government publications.

"There have been three checklists of government publications.... The third, which was much more inclusive and a monumental work of incalculable value covering the entire period of United States publications to $1909 \ldots$ was published in 1911 .

"A fourth edition, bringing the third edition to date, is the aid to government publications most needed by the librarians."

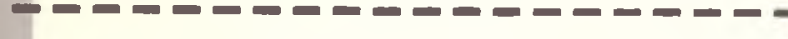

TO: U.S. Historical Documents Institute

1647 Wisconsin Ave., N.W., Wash., D.C. 20007

Please record our order for:

The Dual-Media, Checklist of United States

Public Documents, 1789-1970. (118 microfilm

cartridges and index volumes) ..... \$2,550.

Semi-Annual Cumulative Updating Service, 1971

Annual Subscription (includes cumulations as of June 30, and December 31st, 1971) . \$275.00.

Set of 5 index volumes only .... \$212.50.

Name

Address

City State Zip

Deduct $5 \%$ from all prices on pre-paid orders.

\section{SEPARATE SUBSETS OFFERED FOR MAJOR GOVERNMENT AUTHORS}

Department level author breakouts are available separately upon request. For example, you may order individual microfilm reels covering the shelf lists of publications of the Department of Agriculture, Interior Department, Health, Education and Welfare. Please write for price information.

$1,200,000$ shelf list cards on $16 \mathrm{~mm}$ microfilm (roll or cartridge)

anged in SuDocs classification order by some current as of October 1970.

The active file contains approximately 550,000 cards describing publications of existing government authors and continuous series.

The inactive file contains 650,000 cards describing publications in discontinued series and items longer active.

Also, both files contain about 50,000 guide cards which indicate changes of titles and identify predecessor and successor organizations. 


\section{ical Documents Institute}

\author{
the U.S. Public Printer
}

of Documents announces the

IST OF



1) media collection of the Active and Inactive shelf the Superintendent of Documents', Public Docubrary, Washington, D.C.
The most comprehensive single source of published information on U.S. Government Documents."

Carper W. Buckley

U.S. Superintendent of Documents 1953-1970

\section{BIBLIOGRAPHIC DATA ON \\ MORE THAN 1.5 MILLION}

U.S. GOVERNMENT PUBLICATIONS

Now available to librarians for the first time in any format. As stated by Carper W. Buckley, who until his retirement in 1970 had served as U.S. Superintendent of Documents since 1953.

"Checklist"70 provides librarians with the most comprehensive single source of published information about United States Government documents. It lists all titles which appear in the shelf lists of the Public Documents Library of the U.S. Government Printing Office, covering the period 1861 through October 1970. Also included are the publications listed in the Checklist of U.S. Public Documents, 1789-1909, the Monthly Catalog and Mary Elizabeth Poole's Documents Office Classification to 1966."

Each citation is at least as complete as the entries in the Monthly Catalog and often provides more information. For instance, bibliographic data on each issue of certain periodicals are included, as well as complete cross-references for changes in classification numbers, titles, or issuing agencies. Cutterized separates are listed for some series publications.

\section{IN BOUND VOLUMES - NOW AVAILABLE FOR INDIVIDUAL PURCHASE}

These five full size indexes to the microfilm collection are now being supplied as part of the dual media edition and are also for the first time being made available as individual volumes. All but Index IV were computer generated and were compiled by Mr. and Mrs. Daniel and Marilyn Lester of Mankato State College in Minnesota.

INDEX I. SUDOCS CLASSIFICATION ORDER INDEX OF U.S. GOVERNMENT AUTHOR-ORGANIZATIONS, 1789-1970 lists the names of some 6000 government "author-organizations" in SuDocs Class order showing microfilm reel numbers.

casebound $\$ 42.50$

INDEX II. U.S. GOVERNMENT AUTHOR-ORGANIZATION INDEX, 1789-1970 arranged alphabetically by the official names of 6000 active and inactive publication-issuing offices. This index brings together all SDC numbers for any issuing office regardless of its reorganization history.

casebound $\$ 42.50$

INDEX III. DEPARTMENTAL INDEX TO U.S. GOVERNMENT AUTHOR-ORGANIZATIONS, 1789-1970 contains a breakdown of Government issuing offices listed alphabetically under the cabinet level departments or major agencies to which they report.

casebound $\$ 42.50$

INDEX IV. U.S. GOVERNMENT SERIAL TITLES, 1789-1970 Note: This index volume has been substantially expanded in size and scope since our initial announcement. It now contains not only an alphabetical listing of 18,000 current and discontinued serial titles contained in the Serials card File of the Public Documents Library (with their SDC numbers and microfilm reels), but also their bibliographic histories and other annotations. This additional information was obtained by checking each title against the microfilm copies of the shelf list cards in both the active and inactive files.

casebound $\$ 52.50$

\section{PLUS OUR NEWLY ANNOUNCED ADDITION TO THE CHECKLIST '70 INDEX SET}

INDEX V. KEYWORD INDEX TO THE PUBLICATION-ISSUING OFFICES OF THE U.S. GOVERNMENT, 1789-1970 Note: This computer generated index was recently added to the 4 originally offered with Checklist '70, in order to provide a form of subject access to the massive collection. It lists the 6000 Government "issuing offices" under some 27,000 subject oriented keyword entries. Because of the unusual length and descriptive nature of the names of U.S. Government offices, this keyword index provides a surprising degree of subject access. The fact that each "issuing office" is listed under an average of 4.5 descriptive entries (even after the exclusion of such general words as "bureau", "committee", etc.), attests to the effectiveness of the index. SDC numbers and reel numbers are repeated in each entry.

casebound $\$ 52.50^{\circ}$ 


\section{Introducing - the newest addition to the READER SERIES IN LIBRARY AND INFORMATION SCIENCE \\ READER IN AMERICAN LIBRARY HISTORY edited by Michael H. Harris}

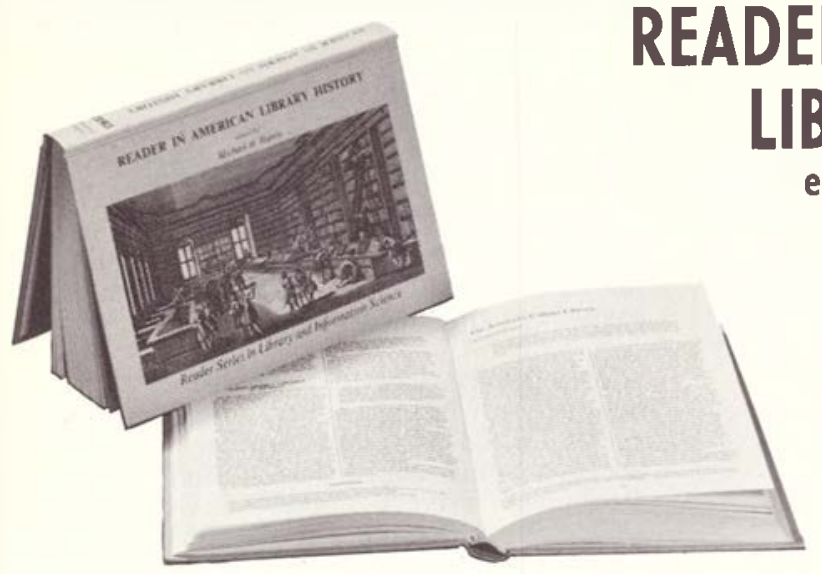

\section{OTHER READERS IN THE SERIES}

\section{READER IN LIBRARY \\ ADMINISTRATION}

Edited by Paul Wasserman and Mary Lee Bundy

Shows the complexity of the modern library organization and identifies important issues facing administrations rather than focusing upon techniques and providing solutions or formula.

$\$ 10.95$ if billed*

$\$ 9.95$ payment with order* *

READER IN RESEARCH

METHODS FOR

LIBRARIANSHIP

Edited by Mary Lee Bundy and Paul Wasserman

Concerns itself with the design and conduct of research as wel as the philosophical and social implications of research on librarianship.

\$11.95 if billed

\$10.95 payment with order**
"This volume is intended to contribute to the reader's understanding of the historical development of libraries and 11brarianship in America from the colonial period to the early twentieth century. An examination of American library history shows how the role of the library has been defined and redefined through the years, and will illuminate those social needs that stimulated the rise and encouraged the support of libraries over the past 300 years." from the preface. 242 pp. $\$ 10.95$ if billed". $\$ 9.95$ payment with order**.

To: Dept. ACR1-D, NCR/Microcard Editions, 901 26th Street, N.W., Washington, D.C. 20037

This series, under the general editorship of Dr. Paul Wasserman brings together previously published articles required for a comprehensive view of major topics in library science. It includes material from a wide range of disciplines in addition to the traditional literature of librarianship. The Series is invaluable for use as texts for courses in library science, supplementary course reading, a focus for seminar discussion, individual study.

$\square$ Please send me ........ copies of Reader in American Library History at $\$ 10.95$ each (\$9.95 if payment is enclosed).

$\square$ Please send me ........ copies of Reader in Library Administration at $\$ 10.95$ each (\$9.95 if payment is enclosed).

$\square$ Please send me ......... copies of Reader in Research Methods for Librairianship at $\$ 11.95$ each (\$10.95 if payment is enclosed).

$\square$ Please send me ........ copies of Reader in the Academic Library at $\$ 10.95$ each ( $\$ 9.95$ if payment is enclosed).

$\square$ Please send me ........ copies of Reader in Library Services and the Computer at $\$ 9.95$ each ( $\$ 8.95$ if payment is enclosed).

* Plus Postage. * Postage paid. Sales to individuals on pre-paid basis only. Wisconsin residents add $4 \%$ sales tax. Sales outside the U.S.A. on pre-paid basis only.

\section{Name}

Institution

Address

City

State Zip

\section{READER IN THE ACADEMIC LIBRARY}

Edited by Michael M. Reynolds tive of the nature of higher education and of library administration, as opposed to describing operational innovations or giving histories of particular libraries.

$\$ 9.95$ payment with order**

READER IN LIBARY SERVICES AND THE COMPUTER

Edited by Louis Kaplan

Emphasis is on the computerized library as seen from the management and administrative point of view; not on the technical or theoretical aspects of computer applications.

s9.95 if billed

$\$ 8.95$ payment with order** 
Socialization as a Function of Higher Education, rev, of, 396 97

Haro, Robert P., rev., 487

Hayes, Robert M., exchange of letters with Ellsworth Mason on evaluating univ, collections, $1967 / 68,384-88$

Healey, James S., "Public-academic 1. cooperation," 121-26

Hean, Evelyn Lorna, The Function of the $L$. in a Coll. of Advanced Education, rev of 487

Henderson, Shannon J., letter to the editor, 382

Henley, J. P., Computer-Based L. and Information Systems, rev. of, 151-52

Hershfield, Allan, "L. service to social scientists," editorial, $349-50$

Hibbs, Jack E., rev., 320-21

Hoadley, Irene Braden, "Of making many books; a l. publication program," 31-35

Holmstrom, Engin I., "An overview of the first four years of the Title II-B fellowship program," 205-16

Hopp, Ralph H., letter to the editor, 384 ; appt. \& port., s211

Horecky, Paul, ed. East Central Europe; a Guide to Basic Pub. lications, rev of 46-48

Hovde, $\mathrm{O}$. M., letter to the editor, 383

Hubbard, Willis M., rev., 322-23

\section{$\mathrm{I}$}

"Increased control through decreased controls: a motivational approach to a 1 . circulation problem," Zelkind and Sprug, 222-26

Index to American Little Mag azines 1920-1939, Goode, comp., rev, of, 55-57

"Information dissemination in education: a status report," Marron and Sullivan, 286-94

"The information explosion; or, redundancy reduces the charge!' Voos, 7-14

Interlibrary Loan Involving Academic Ls., Thomson, rev. of, 53-54

Interlibrary loans, 217-21; Ohio, 197-204

International Conference on African Bibliography, Nairobi, 1967. The Bibliography of Africa; Proceedings and Papers, Pearson and Jones, eds., rev. of, 229

Introduction to Cataloging. Vol 1: Descriptive Cataloging and an Overview of Catalogs and Cataloging, Boll, rev. of, 231 32

Irvine, Betty Jo, "Slide classification: a historical survey," 2330

\section{J}

Jansen, Guenter A., rev., 319-20

Jeffries, A. E., ed., U.K. MARC Project: Proceedings of a Seminar (March 1969) Organized by the Cataloguing and Indexing Group of the $L$. Association, rev. of, 230-31

Jencks, Louise $A_{1}$, letter to the editor, 382-83

Jones, Ruth, ed., The Bibliography of Africa; Proceedings and Papers of the International Conference on African Bibliography, Nairobi, 1967, rev. of 229

The Joseph Jacobs Directory of the Jewish Press in America, rev. of, $398-99$
Josey, E. J., ed., The Black Ln. in America, rev. of, 320

\section{K}

Kane, Joseph Nathan, Nicknames and Sobriquets of U.S. Cities and States $2 \mathrm{~d}$ rev of, 55

Kaplan, Louis, ed., Reader in $L$. Services and the Computer, rev. of, $488-89$

Kaser, David, rev., 317-18

Katalog, Leo Baeck Institute, rev. of, 232-34

King, Clyde, letter to the editor 389

Kinney, John M., “The Texas Consortium to Microfilm Mexican Archival Resources," 376 80

Kirk, Thomas, "A comparison of two methods of 1 . instruction for students in introductory biology," 465-74

Kraus, Joe W, rev., 50-51

\section{L}

Ladenson, Alex, rev., 483-84

Laird, W. David, letter to the editor, 382

Larson, A. Dean, rev,, 320

"Legislative naivete of lns.," Dougherty, editorial, 181

Leimkuhler, Ferdinand $F_{\text {, " "Cost }}$ accounting and analysis for univ. 1s.", 449-64

Leo Baeck'Institute, Katalog, rev. of, $232-34$

Leonard, Lawrence E., Management and Costs of Technical Processes: a Bibliographical Review, 1876-1969, rev. of, Review, 1876-1969,

Letters [to the editor], $64 ; 145$ $47 ; 227-28 ; 315-16 ; 381-92$ 479-82; s127-28

The Librarian Speaking: Interviews with Univ. Lns., Lyle, rev, of, 323-24

Librarianship and Literature: Essays in Honour of Jack Pafford, Milne, ed., rev. of, 394-95

Libraries in France, Ferguson, rev. of, 484

Library Issues: the Sixties, Moon and Nyren, eds., rev. of, 50

Library Lighting, Metcalf, rev. of, 393

"The library lobby," Ralston, 427-3I

"The library reserve system-another look," Carmack and Loeber, 105-09; comment, 228 315

"Library service to social scientists," Hershfield, editorial, 349-50

Library Systems Analysis Guidelines, Chapman, St. Pierre and Lubans, rev. of, 318-19

Line, Maurice B., rev., 394-95

Lipetz, Ben-Ami, User-Requirements in Identifying Desired Works in a Large $L$., rev. of, 395-96

Loeber, Trudi, "The 1. reserve system-another look," 10509 ; comment, 228,315

Lubans, John, "Nonuse of an academic 1." 362-67; $L$. Systems Analysis Guidelines, rev. tems Analysis
of, 318-19

Lyle, Guy R., The Ln. Speaking: Interviews with Univ. Lns., rev, of, 323-24

\section{M}

McGrath, William E., "Correlating the subjects of books taken out of and books used within an open-stack 1.," 280-85; comment, 482

Management and Costs of Technical Processes: a Bibliographical Review, 1876-1969, Dougherty and Leonard, rev. of, 148 49

Management Personnel in Ls.: a Theoretical Model for Analysis, Plate, rev. of, 398

Marron, Harvey, "Information dissemination in education: a status report," 286-94

Martin, Susan K, letter to the editor, 383

Mason, Ellsworth, "The great gas bubble prick't; or, Computers revealed-by a gentleman of quality," 183-96, comment, $316,388-92,480$; letter to the editor, 315-16; exchange of letters with $R$. M. Hayes on evaluating univ. collections, evaluating univ; collections,

Massachusetts, Univ., L., central book processing center, s89-90

Massman, Virgil F., "Book selection: a national plan for small academic Is.," 271-79; comment, 480-82

Maxfield, Grace K., comment on N. D. Stevens' "Work week," s 127

Meadows-Hills, Gordon H., letter to the editor, 146

Medical L Association, Hand book of Medical L. Practice, $3 d$ ed., rev. of, $397-98$

Metcalf, Keyes D., L. Lighting, rev. of 393

Milby, T. H., "Sources of professional staff in selected academic Is." "442-48

Mills, James Cobb, rev., 54-55 Milne, A. T., ed, Lnship. and Literature: 'Essays in Honour of Jack Pafford, rev. of, 39495

Miniter, John J., teaching award, s 91

Moon, Eric, ed., L. Issues: the Sixties, rev. of, 50

Munn, Robert F., letter to the editor, 381-82

Murphy, Anne Marie, appt. \& port., s143

Murray, Sandra Rice, rev., 487 . 88

N

Necrology, s213; s261; s349

"News from the field" s5-18. s38-54; s68-8I; s93-102; s13242; s175-90; 206-10; s249-56 s279-88; s300-12; s327-32, 345

"News from the Sections," s18. s54; s102; s143; sI90; s257; s346

Nicknames and Sobriquets of U.S Cities and States, 2d ed., Kane and Alexander, rev. of, 55

"Nonuse of an academic 1.," Lubans, 362-67

Nyren, Karl, ed., L. Issues: the Sixties, rev. of, 50

O

"Of making many books: a 1 publication program," Davis, Boone and Hoadley, 31-35

Olson, David R., "Book selection: a national plan for small academic ls.," 271-79; comment, 480-82

Orne, Jerrold, rev., 229-30

Ottersen, Signe, "A bibliography on standards for evaluating 1s.," 127-44

"An overview of the first four years of the Title II-B fellowship program," Holmstrom and El-Khawas, 205-16 


\section{$\mathrm{P}$}

Painter, Ann F., rev., 230-31; 488-89

Parker, J. Carlyle, letter to the editor, 315: comment on N. D. Stevens' "Work Week," s127

Pearson, J. D., ed., The Bibliog raphy of Africa; Proceedings and Papers of the International Conference on African Bibliography, Nairobi, 1967, rev. liography

Personnel, s18-2I, 23; s55-59; s82-84; s107-15; s143-44; s193-194; s211-13; s259-61; s288-89; s313-17; s346

Pierson, Robert M. "The proposed standards for faculty status: a dissenting opinion," SI2I-25, 127

Plate, Kenneth H., Management Personnel in Ls.: a Theoretical Model for Analysis, rev. of, 398

The Plateglass Univs., Beloff, rev. of, 320-21

Powell, Lawrence Clark, rev., 48 49

Powell, Ted F., rev., 151

Problems in Univ. 'L. Management, ARL, rev, of, 229-30

“A proposal for a National Institute of L. Science," Axford, editorial, 425-26

"Public-academic 1. cooperation," Healey, 121-26

\section{Q}

“Quest for expertise: a ln.'s responsibility," Stone, 432-41

\section{$\mathrm{R}$}

Radical Research Center, Carleton Coll. Alternative Press Index, rev, of, 51-53

"Railroad tracks and alphabet soup," Edmonds, editorial, 269-70

Ralston, Anthony, "The 1. lobby," 427-31

Reader in L. Services and the Computer, Kaplan, ed., rev. of, 488-89

Reader in the Academic $L$. Reynolds, rev. of, 150-51

"Reference books," Sheehy, 3645; 304-14

Reichmann, Felix, rev., 46-48

Retirements, s23; silis; s144 s212-13; s260-61

Reynolds, Michael M., ed, Reader in the Academic L., rev. of 150-51

Rink, Bernard C., letter to the editor, 383

Robinson, Harry, rev., 322

Rocq, Margaret Miller, ed., California Local History: a Bibliography and Union List of $L$. Holdings, $2 \mathrm{~d}$ ed., rev. and enl. Holdings, $2 \mathrm{~d}$ ed.

Roseberry, Cecil R., For the Government and People of This State: a History of the New York State L., rev. of, 486-87

Roselle, William C., appt. \& port., s313

Rosenberg, Victor, rev., 151-52

Rossell, Glenora Edwards, appt. \& port., s82

Ryan, Pat M., Black Writing in the U.S.A., a Bibliographic Guide, rev. of, $487-88$

\section{S}

Sachtleben, Carl, appt. \& port., s211

St. Pierre, Paul L., L. Systems
Analysis Guidelines, rev. of 318-19

Schmidt, C. James, "A cooperative interl. loan service for the state-assisted univ. Is. in Ohio," 197-204

Scientific and Technological Documentation: Archival Evalu ation and Processing of Univ. Records Relating to Science and Technology, Brichford, rev, of, 484-85

"Security problems in coll. and univ, 1s.: student violence," Davis, 15-22

Shaffer, Kay, "A cooperative interl. loan service for the state assisted univ. ls. in Ohio," 197 204

Shaffer, Kenneth R., rev., 398

Shank, Russell, "Democratization and the ALA Council," editorial, s219

Sheehy, Eugene P., "Selected ref. books," 36-45; 304-14

Silvester, Elizabeth, letter to the editor, 382

Simkin, Faye, Cooperative Resources Development: a Report on a Shared Acquisitions and Retention System for METRO Ls., rev, of, 483-84

"Slide classification: a historical survey" Irvine, 23-30

Smith, Eldred, rev., 234-36

Smith, John B., appt. \& port., s55 "Sources of professional staff in selected academic Is.," Milby, 442-48

The Southern Historical Collection: a Guide to Manuscripts, Blosser and Wilson, rev, of, 149-50

Spahn, Theodore Jurgen, rev., 5I53

Sparks, David E., appt. \& port., s259

Spence, Melville R, appt. \& port., $\mathrm{s} 107$

Spence, Paul H., rev. 55

Sprug, Joseph, "Increased control through decreased controls: a motivational approach to a 1 . circulation problem," 222-26

circulation problem," 222-26
Spyers-Duran, Peter, letter to the


s 107,109

Standards for Faculty Status, proposed revisions, s35-37; comment by $\mathrm{R}$. M. Pierson, s12125, 127; approved, s217

"Standards for Junior Coll. Ls.," 1971 rev, text, s265-78

Stanford Univ., System Scope for L. Automation and Generalized Information Storage and Retrieval at Stanford Univ., rev. of, 236-38

Stenstrom, Ralph $\mathrm{H}_{\text {, }}$ Cooperation Between Types of Ls. I9401968: an Annotated Bibliography, rev. of, $485-86$

Stevens, Norman D., "Work week," s38, 41; comments, s127-28; rev, 150-51, 395-96

Stokes, Katharine M., "From inside the DLP," s1-2; s37; s67; s91; s131-32; s175; s205; s246; s278

Stone, Elizabeth W., "Quest for expertise: a ln,'s responsibility," 432-41

Student Activism in American Higher Education, Ellsworth and Burns, rev. of, 322-23

The Subject Approach to Information, Foskett, rev, of, 15354

Sullivan, Patricia, "Information dissemination in education: a status report," 286-94

Swanson, Rowena, letter to the editor, $388-89$
System Scope for L. Automation and Generalized Information Storage and Retrieval at Stanford Univ., Stanford Univ., rev. of, 236-38

Sustems Analysis of a Univ. L. Final Report on a Research Project, Buckland et al., rev. of, 152-53

Szilassy, S., letter to the editor, 384

\section{$\mathbf{T}$}

Taylor, Robert S., letter to the editor, 381

"A tentative analytical approach to the determination of interl. loan network effectiveness," Warner, 217-21

"The Texas Consortium to Microfilm Mexican Archival Resources," Kinney, 376-80

Thomson, Sarah Katherine, Interl. Loan Involving Academic Ls., rev. of, 53-54

Title II-B fellowships, 205-16

Turner, Mrs. Ronald C., letter to the editor, 381

\section{U}

U.K. MARC Project: Proceedings of a Seminar (March 1969) Organized by the Cataloguing and Indexing Group of the $L$. Association, Jeffries and Wilson, eds. rev. of, 230-31

The United Nations $L$. Its Origin and Development, Dale, rev. of $321-22$

Uridge, Margaret D., rev., 53-54

User-Requirements in Identifying Desired Works in a Large L., Lipetz, rev, of, 395-96

$\mathrm{V}$

Voos, Henry, "The information explosion; or, redundancy reduces the charge!" 7-14; rev., $153-54,318-19$

\section{W}

Walters, Mary Dawson, comp., Afro-Americana: a Comprehensive Bibliography of Resource Materials in the Ohio State Univ. Ls. by or About Black Americans, rev. of, 48788

Warner, Edward S., "A tentative analytical approach to the determination of interl. loan network effectiveness," 217-21

Webb, W. H., "The greening of the 1 . " 5; comment, 227-28

White, Lucien $W$., appt. \& port., s346

Williamson, W. L., rev, 396-97

Willocks, $R$, Max, rev 321-22

Wilson, Clyde N., Jr., The Southern Historical Collection: a Guide to Manuscripts, rev. of, 149-50

Wilson T. D., ed, U.K. MARC Project: Proceedings of a Seminar (March 1969) Organized by the Cataloguing and Indexing Group of the L. Association, rev. of, 230-31

Wynne, Dorothy E., letter to the editor, 227

Z

Zafren, Herbert C., rev., 398-99

Zelkind, Irving, "Increased control through decreased controls: a motivational approach to a 


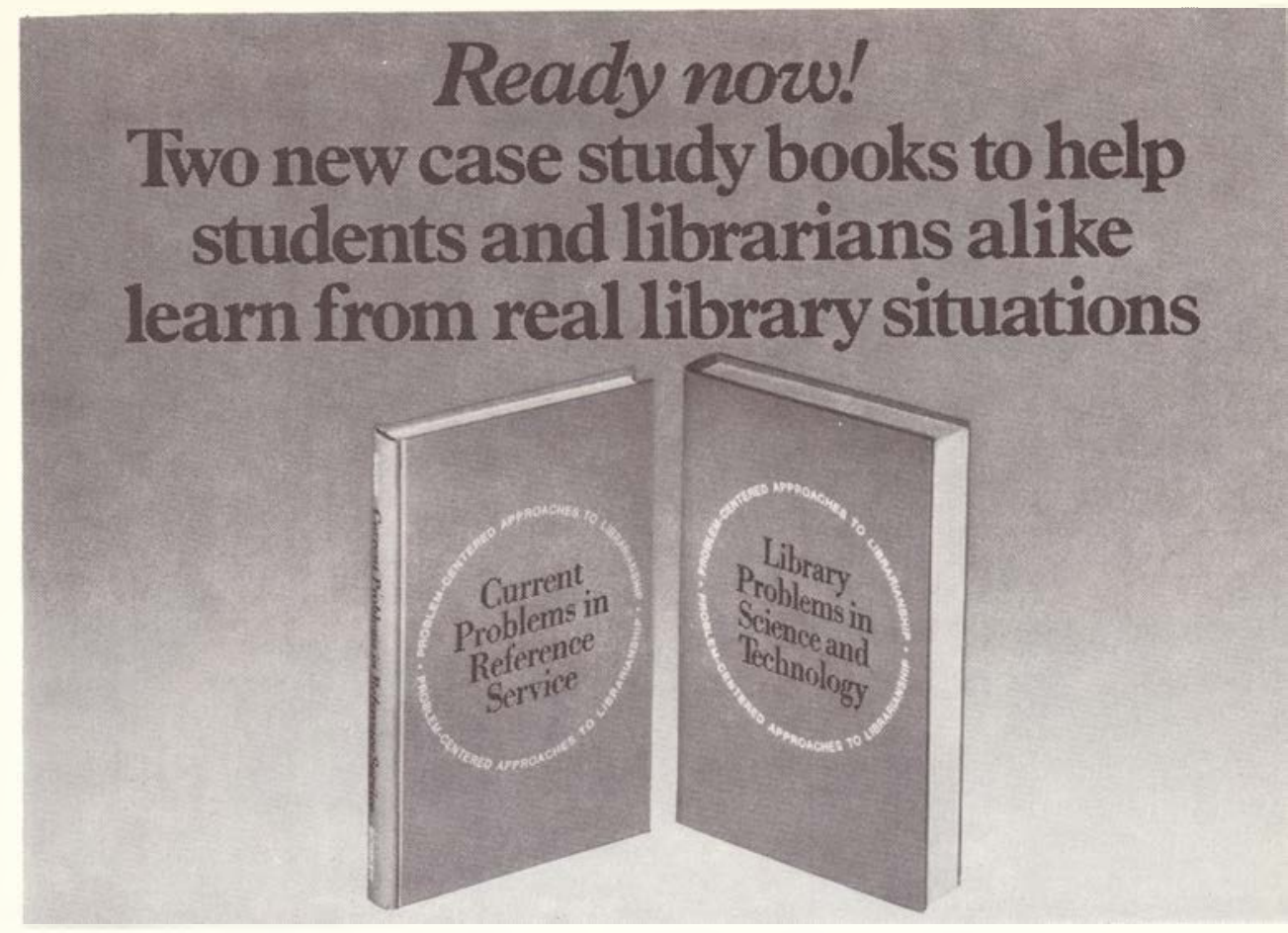

\section{CURRENT PROBLEMS IN REFERENCE SERVICE}

by Thomas J. Galvin

$6 " \times 9 " .162$ pages. $\$ 9.95$ net pp.

$\mathbf{2 0 \%}$ off on 5 or more.

Here are 35 case studies based on actual, emerging political and social issues which might arise in any modern library. They offer remarkable learning and teaching experiences for anyone concerned with libraries because they help the reference librarian, library student and library administrator to identify, analyze, judge and resolve such problems as requests for reading lists on sex education... library service in open-admissions colleges ... application of performance budgeting to reference service . . . and more. LC 77-162527. June 1971.

\section{LIBRARY PROBLEMS IN SCIENCE AND TECHNOLOGY}

by James $\mathbf{M}$. Matarazzo

$6^{\prime \prime} \times 9^{\prime \prime} .191$ pages. $\$ 9.95$ net pp.

$20 \%$ off on 5 or more.

These 35 realistic case studies are designed to help students in pre-service and in-service programs, graduate classes, seminars and workshops master the sources and uses of scientific literature, and make the information available to a variety of clientele, from the young to the advanced researcher. The case studies cover the whole spectrum of complex literature and administrative problems involving scientific reference questions and sources ... dissemination of scientific information ... library planning, policy and supervision.... collection building . . . and more. LC 70-164033. November 1971.

Both volumes are part of the Bowker Series, "Problem-Centered Approaches to Librarianship," edited by Professor Thomas J. Galvin of the School of Library Science, Simmons College.



Published by R. R. Bowker Company/A XEROX EDUCATION COMPANY 


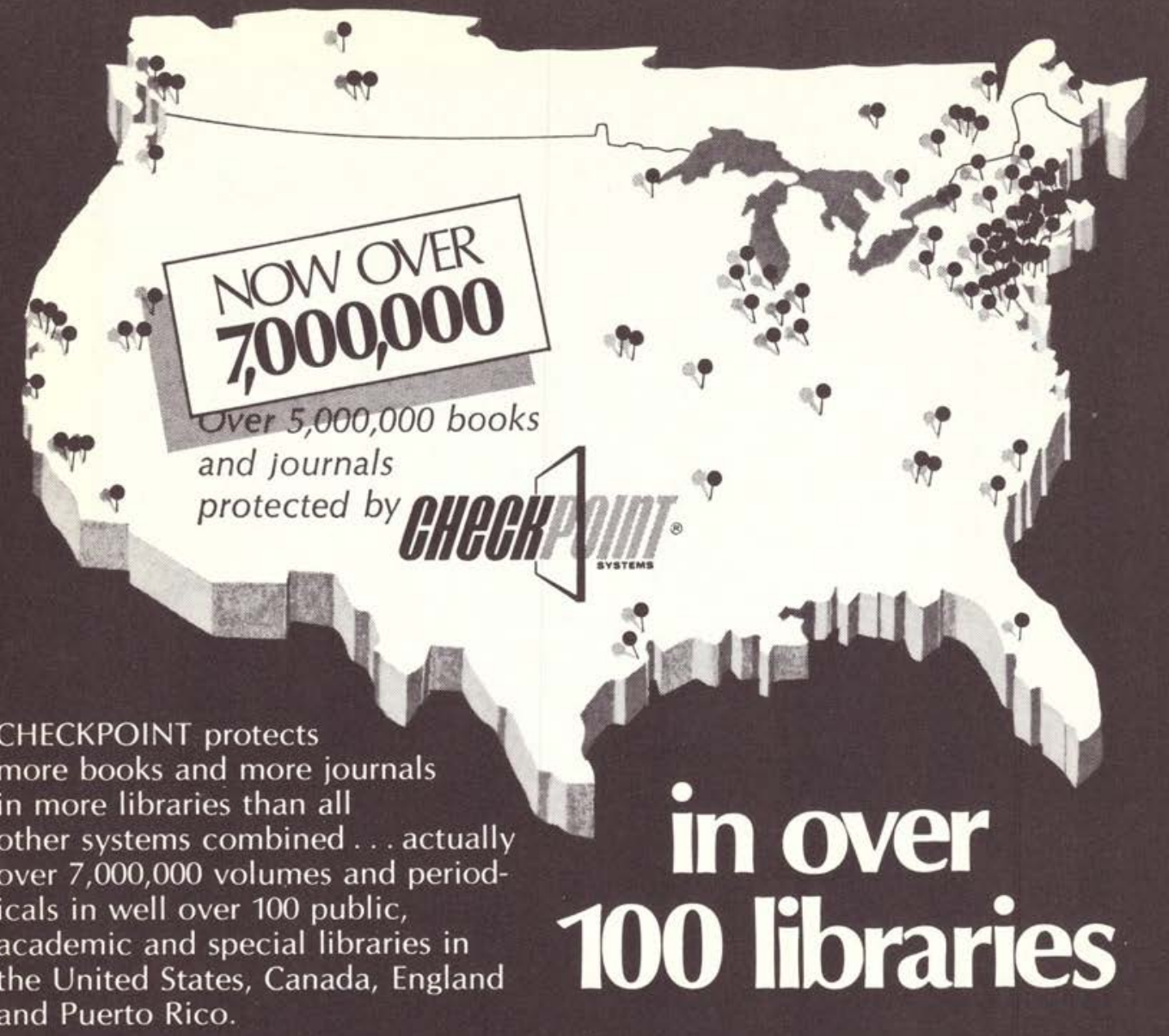

Why the overwhelming preference for CHECKPOINT?

CHECKPOINT is reliable because it is designed on superior scientific principles ... can't be circumvented by shielding or otherwise.

CHECKPOINT is silent and unobtrusive ... accidental carry-out or deliberate pilferage are stopped instantly... without offending the patron or embarrassing the staff.

CHECKPOINT performs as promised... documented inventories prove book losses are reduced by almost 90 percent.

CHECKPOINT protects your entire collection ... eliminates the need for closed stacks or restricted reserves. With CHECKPOINT you can relax.

Let us take you to inspect a nearby CHECKPOINT installation. Or ask us to send additional information. No obligation, of course.

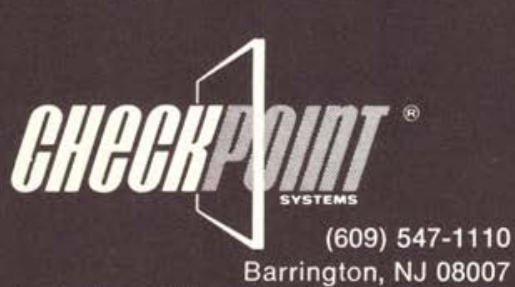

A Member of Logistics Industries Corp.
Represented by



GAYLORD BROS., INC. LIBRARY SUPPLIES AND EQUIPMENT SYRACUSE, NY 13201 - STOCKTON, CA 95201 
ered upon acceptance of 1971 Aspen Humanistic Award by the French statesman, economist, and president of the "Action Committee for United States of Europe," an organization of leading political, business, and labor leaders of six nations of the Common Market and the U.K. The speech briefly describes the rationale behind the formation of the United States of Europe and the goals which it feels are essential to the future of Western Europe.

"A View from the White House," lecture delivered by Max Frankel, chief of the Washington Bureau of the New York Times, at the Aspen Institute, 1970. It presents a reflective view of the U.S. presidency, defining the terms by which our society must choose a president and the power which it is willing to have the president exercise.

"The Future of American Labor," lecture delivered by Gus Tyler, assistant president of the International Ladies' Garment Workers' Union, at the Aspen Institute, August 1970. Tyler gives an incisive account of the rise of trade unionism in the U.S. and an analysis of the crucial problems which it now faces.

- A new publication, Journal Holdings of Maine Libraries, has just been printed. The seven hundred and seven-page edition lists the journal holdings of thirty-one academic, public, and special libraries in the state of Maine. This computer-based list contains over 30,000 entries of the major libraries in the state. The book is available at $\$ 5.00$ each from Mr. William C. Ahrens, Assistant University Librarian, University of Maine, Orono, ME. Checks should be made out to the University of Maine.

- The August 1971 issue of the list of "Graduate Library School Programs Accredited by the American Library Association" is available upon request from the Committee on Accreditation, American Library Association, 50 E. Huron St., Chicago, IL 60611. Issued semiannually by the ALA Committee on Accreditation, the official list gives the name and address of each library school offering an accredited program, the name of the dean or director, and the name of the degree to which the accredited program leads. Library schools offering doctoral and postmaster's specialist or certificate programs are so designated on the list.

\section{Have you renewed your membership? ACRL NEEDS YOU!}

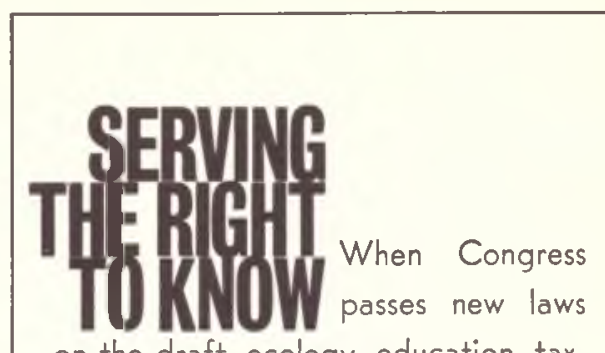

on the draft, ecology, education, taxes, social security, labor, it affects everyone-the student, the citizen, the businessman, the instructor. To serve their need and right to know about and study these laws you can provide them with UNITED STATES CODE ANNOTATED. It contains all the permanent laws enacted by Congress. Easy to find, easy to understand. Also included are paragraph summaries of all reported court decisions involving these laws. And USCA can be kept absolutely current with all the new laws through U.S. CODE \& CONGRESSIONAL NEWS. information on UNITED STATES CODE ANNOTATED, U.S. CODE \& CONGRESSIONAL NEWS and every other type of law book published is available from

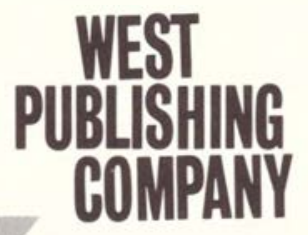

St. Paul, Minn. 55102 $612 / 228-2759$

Legal publishers since 1876 